\title{
OBSERVATIONS ON THE MUTUAL RELATIONSHIPS AMONG SOIL MICROORGANISMS
}

\author{
K. G. MUKERJI \\ Department of Botany, University of Delhi, Delhi 7, India
}

(Received May 21, 1968)

\begin{abstract}
The observations made on the relationships existing between various microorganisms isolated from natural sources have been described. The species of Chaetomium were found to be antagonistic towards some other fungi. Competition among microorganisms was noticed in many instances. Mutualistic symbiosis was found to occur between a sterile strain of Thielavia setosa, which formed cleistothecia only in the presence of other fungi like Aspergillus nidulans, A. variecolor, Thielavia sepedonium, and T. terricola.
\end{abstract}

Soil is a complex medium and one of the main natural substrates for saprophytic growth. It contains numerous microbial communities. The associative effects and interrelationships of these communities or individuals are not obvious in soil, but when plated on suitable agar media they become distinct and visible (1-4). The mutual behaviour of these organisms depends mostly on the environmental conditions, nutrition and the substrate on which they grow (5).

The microflora of any habitat is governed by the biological equilibrium created by the associations and interactions of all individuals present in the population. The microorganisms depend upon one another for certain growth factors, but at the same time they exert detrimental influences, so that both beneficial and harmful effects are evident (6). ODUM (7) has classified the interactions occurring between two microorganisms in an association as follows : (a) both behaving independently (neutralism); (b) each relying upon the other, and both benefiting (symbiosis); (c) both benefiting in association but the cooperation is not necessary for their existence (protocooperation); (d) one is benefited while the other is unaffected (commensalism); (e) suppression of one organism as the two species are struggling for limited oxygen supply, nutrition, space etc. (competition); (f) one is suppressed and the other not affected (ammensalism and antagonism); ( $\mathrm{g}$ ) and one directly attacking the other (parasitism or predation). Antagonism between species plays an important role in governing the distribution and population size of the soil-inhabiting fungi, but equally important is the general antagonism of the soil that prevents spores from germinating or hyphae from growing $(8)$. 
The author and his coworkers have been carrying out taxo-ecological investigations of the Indian soil microfungi during the years 1957 to 1967, and have observed several interesting facts concerning their interrelationships. These are being recorded in this paper.

\section{MATERIALS AND METHODS}

Soil samples were collected from various localities in India (Table 1). These included all types of soils, i.e., normal-cultivated and noncultivated, alkaline and acidic. They were taken from different horizons (below $66^{\prime \prime}, 12^{\prime \prime}$ and $\left.18^{\prime \prime}\right)$. These samples were collected under aseptic conditions and there $\mathrm{pH}$ was tested on the spot. In most cases samples were processed immediately after reaching the laboratory, failing which, they were stored at temperatures between 10 to $12^{\circ}$, until analysed. About 1,000 samples have been analysed for this purpose during the period of this investigation. Several isolation techniques were employed, but the dilution plate method of WAKSMAN (9) was the one that was followed for quantitative determination of the microflora. Four soil dilutions $(1: 100,1: 1,000,1: 10,000$, and $1: 100,000)$ were made using Emerson's technique (10) and four replicates were prepared for each dilution using $(1 \mathrm{cc})$ as inoculum. Several media were used for plating, but the ones which proved good were Brown's Synthetic medium and Czapek's agar. Rose bengal and streptomycin was added to these media for checking the excess bacterial growth (11).

A complete record of all the bacterial and fungal colonies appearing in these plates was kept for their ecological relationships (12). The interactions among these microorganisms were also noted and form the subject matter of this paper.

Table 1. Data on soil collections.

\begin{tabular}{l|r}
\multicolumn{1}{c|}{ Locality } & pH range \\
\hline Banthra, district Lucknow & $7.5-10.8$ \\
Chirayyabagh, district Lucknow & $9.0-11.0$ \\
Daliganj, district Lucknow & $6.1-9.2$ \\
Dalyanpur-Kewari, district Lucknow & $8.5-10.0$ \\
Kathouta, district Lucknow & $8.5-10.5$ \\
Kukrail, district Lucknow & $6.4-10.5$ \\
Chakeri, district Kanpur & $7.2-11.0$ \\
Gausganj, district Hardoi & $6.1-8.5$ \\
Sulethu, district Rae Bareli & $8.0-10.5$ \\
Mall road, district Delhi & $6.0-7.5$ \\
Patelnagar, district Delhi & $7.0-7.5$ \\
\hline
\end{tabular}




\section{RESULTS}

A few species of Chaetomium were found to be antagonistic towards certain fungi as shown in Table 2 .

Colonies of Sporotrichum carthusio-viride were found to check the growth of Aspergillus niger (Fig. 1) and A. nidulans (13). Instances of fungi growing over other colonies or parasitizing them are cited in Table 3.

Table 2. Showing species of Chaetomium antagonising other fungi.

\begin{tabular}{l|l}
\hline Antagonist & \multicolumn{1}{|c}{ Forms antagonised } \\
C. globossum & Species of Aspergillu; \\
Cpecies of Penicillium \\
Species of Fusarium \\
Species of Cephalosporium \\
Thielavia terricola and a few bacteria \\
Asłergillus niger \\
Aspergillus nidulans \\
Curvularia lunata \\
Curvularia maculans
\end{tabular}

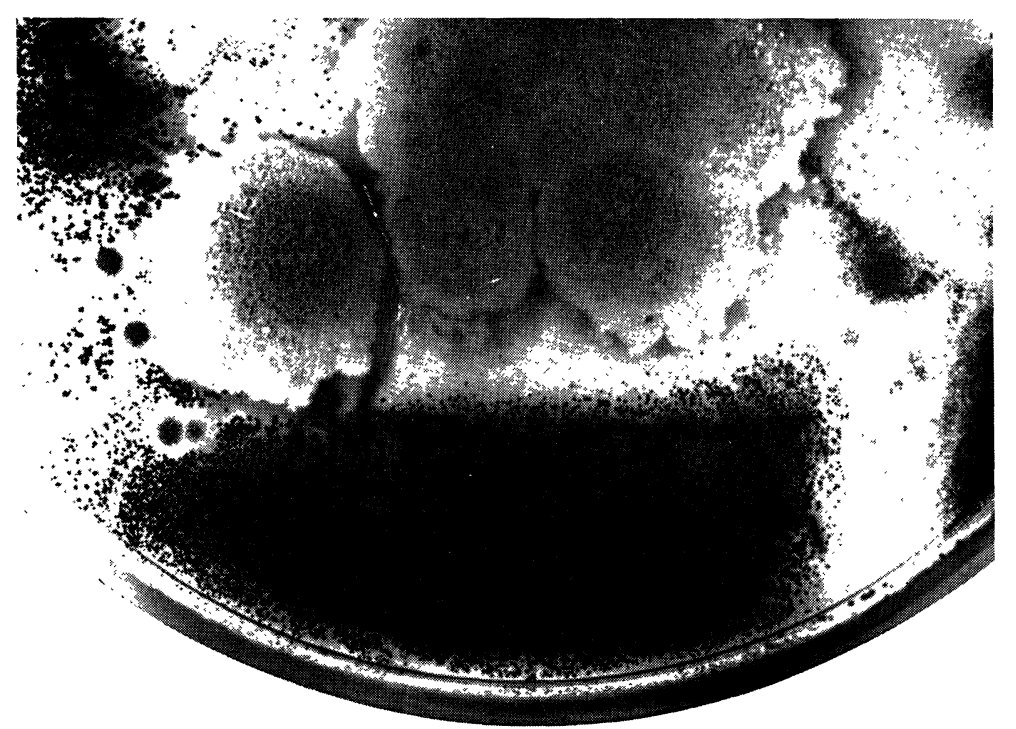

Fig. 1. Colonies of Sporotrichum carthusio-viride checking growth of Aspergiilus niger. 
Table 3. Showing certain fungi growing over mature colonies of other fungi.

\begin{tabular}{|c|c|}
\hline Mature colony of & Over grown by \\
\hline $\begin{array}{l}\text { Aspergillus niger } \\
\text { A. flavus } \\
\text { A. paradoxus } \\
\text { Fusarium oxysporum } \\
\text { F. merismoides } \\
\text { Fusarium spp. } \\
\text { Rhizopus nodosus } \\
\text { R. nigricans }\end{array}$ & Peniciliium nigricans \\
\hline $\begin{array}{l}\text { Aspergillus niger } \\
\text { A. flavus } \\
\text { A. sulphureus } \\
\text { Ascotricha guamensis } \\
\text { Chaetomium funicolum } \\
\text { C. bostrychodes } \\
\text { C. globossum }\end{array}$ & Fusidium terricola \\
\hline $\begin{array}{l}\text { Aspergillus niger } \\
\text { A. fumigatus } \\
\text { A. nidulans } \\
\text { A. flavus } \\
\text { Ascotricha guamensis } \\
\text { Chaetomium globossum } \\
\text { C. bostrychodes } \\
\text { Penicillium lilacinum } \\
\text { Pyrenochaeta decipiens }\end{array}$ & $\begin{array}{l}\text { Cephalosporium acremonium } \\
\qquad \& \\
\text { C. roseo-griseum }\end{array}$ \\
\hline $\begin{array}{l}\text { Aspergillus niger } \\
\text { A. flavus } \\
\text { A. sydowii } \\
\text { A. fumigatus } \\
\text { A. tamarii } \\
\text { Arachniotus citrinus } \\
\text { Gliocladium catenulatum } \\
\text { Penicillium nigricans } \\
\text { P. funiculosum } \\
\text { P. stipitatum } \\
\text { Sporotrichum carthusio-viride (Fig. 2) }\end{array}$ & $\begin{array}{l}\text { Fusarium oxysporum } \\
\text { F. merismoides } \\
\qquad \& \\
\text { Fusarium spp. }\end{array}$ \\
\hline
\end{tabular}


Table 3. Continued.

\begin{tabular}{l} 
Mature colony of \\
\begin{tabular}{l|} 
Circinella muscae \\
$\begin{array}{l}\text { Rhizopus nigricans } \\
\text { R. nodosus } \\
\text { Fusarium merismoides }\end{array}$
\end{tabular} \\
\hline
\end{tabular}

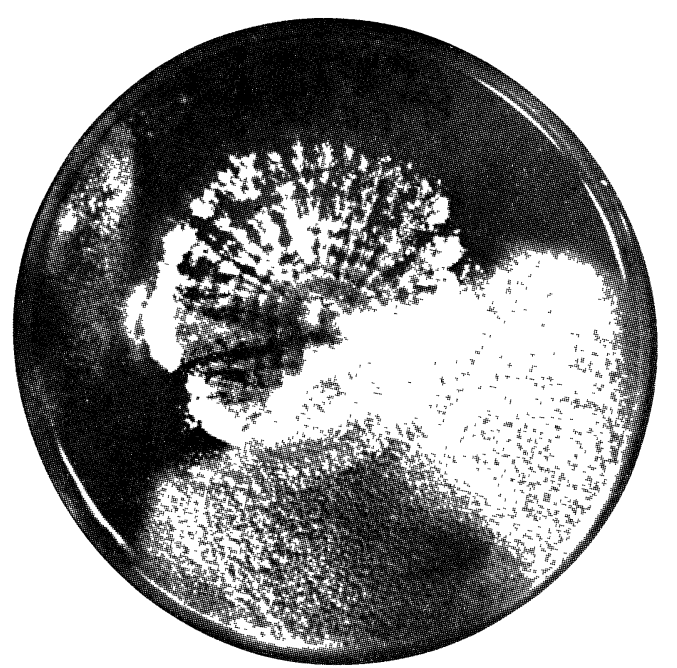

Fig. 2. Fusarium oxysporum overgrowing a mature colony of Sporotrichum carthusio-viride.

Species of Piptocephalis are known to parasitize other mucoraceous forms. $P$. brijmohani, $P$. cylindrospora and $P$. tieghemiana were isolated growing on species of Mucor. P. tieghemiana could also parasitize perithecia of Sordaria humana and pycnia of Phoma hibernica. DoBBS and ENGLISH (14) also found some species of Piptocephalis growing on non-mucoraceous forms.

Several of the actinomycetes and bacteria present in the soil over-power members of Phycomycetes, Ascomycetes and Deuteromycetes. Phycomycetes rarely antagonise other forms. Although some of them, like Cunninghamella, Syncephalastrum, Helicostylum, Mucor and Rhizopus grow over other fungi, but they do no harm to the supporting colony. Some of the members of Acrasiales were quite frequently found to grow in association of certain bacteria.

During several isolations Trichurus spiralis and Penicillium nigricans and T. spiralis and Fusarium oxysporum were found growing together, both maintaining their individuality. Tritirachium roseum and T. dependens were isolated 
in association with a species of Aspergillus and Penicillium, respectively. This observation is in accordance with the findings of RAI and TEWARI (15). Cephalosporium coremioides grew with Pyrenochaeta decipiens without harming each other. Rhizopus nigricans and $R$. nodosus grew well with Aspergillus nidulans and $A$. variecolor without losing their individuality.

During the isolation of fungi from Lucknow soils a sterile strain of Thielavia setosa was found which produced cleistothecia only in the presence of Aspergillus nidulans, A. variecolor, Thielavia sepedonium and T. terricola (16). Spores of Tritirachium and Acremoniella were found to exhibit increased sporulation and growth in the presence of other fungi (17). Recently, a sterile strain of Chaetomium bostrychodes was isolated which produced fertile perithecia only in presence of Cephaliophora irregularis. Surprisingly this sterile isolate of Chaetomium bostrychodes formed fertile perithecia abundantly on potato dextrose agar (PDA) also. It appears that the chemical which is necessary for the formation of fertile perithecia is present in PDA and can be synthesized by Cephaliophora irregularis.

Ecological associations of microorganisms, which do not involve an actual union of the partners, are very common among soil microorganisms. Several fungi and bacteria grow from a single dilution in a culture plate, the forms growing maintain their individual characters, even though, they are much nearer to each other.

\section{DISCUSSION}

The antagonistic behaviour of Chaetomium species towards other microorganisms has been noted by many workers (18-23). Overgrowth of one form on other is very common in isolation plates. In certain cases the host is weakened whereas the attacking fungi remains viable. According to CAULLERY (24) in such intimate and constant associations of two organisms it is not essential that one should be beneficial or detrimental to other party of the relationship. Detailed investigations on this aspect of microorganisms have been done by many workers like BUTLER and KING (25), BACKUS and Stowell (26), Dobbs and Hinson (27), Morton and Stroube (28), Lilly (29), SMith (30) and VienNot-Bourgin (31).

The relationship between a sterile strain of Thielavia setosa and Aspergillus nidulans, A. variecolor, Thielavia sepedonium and T. terricola is very interesting (16). DADE (32) also found similar results with another sterile strain of Thielavia setosa. De VAY (33) keeps such relationships under "mutualistic symbiosis." This type of association has been investigated in several other forms by many workers.

A few fungi are known to sporulate only under the influence of a certain specific fungi (34-37). Ecological associations of the microorganisms occur commonly and are governed by soil conditions, surface vegetation and environmental factors $(38-48)$. 
Thanks are due to Professor B. M. Johri and Dr J. N. Rai for encouragements and to $\operatorname{Dr}$ N. S. Subba Rao of the Microbiology Division, Indian Agricultural Research Institute, New Delhi and Dr R. N. Chopra for critically going through the manuscript.

\section{REFERENCES}

1) P. H. CARter and J. L. Lockwood, Phytopathology, 47, 151 (1957).

2) P. H. Carter and J. L. Lockwood, Phytopathology, 47, 154 (1957).

3) D. PARK, Trans. Brit. mycol. Soc., 40, 283 (1957).

4) D. PARK, Phytopathology, 40, 358 (1957).

5) A. J. OsteraAs, Phytopathology, 46, 22 (1956).

6) E. P. Odum, Fundamentals of Ecology, W. B. Saunders Co., Philadelphia (1959).

7) M. Alexander, Introduction to Soil Microbiology, John Wiley \& Sons, Inc., N.Y., and London. (1961).

8) R. K. Robinson, Ecology of Fungi, The English Universities Press Ltd., London. (1967).

9) S. A. WAKSMAN, J. Bacteriol., 7, 339 (1922).

10) P. Emmerson, Soil characteristics. A field and laboratory guide, McGraw-Hill Book Co., Inc., N.Y. and London. (1925).

11) J. P. Martin, Soil Sci., 69, 215 (1950).

12) K. G. MukerJi, Mycopath. Mycol. appl., 29, 339 (1966).

13) J. N. RaI and K. G. MukerJi, Mycopath. Mycol. appl., 18, 122 (1962).

14) C. J. DobBs and M. P. English, Trans. Brit. mycol. Soc., 37, 375 (1954).

15) J. N. RaI and J. P. Tewari, Proc. Indian Acad. Sci., 54B, 209 (1961).

16) K. G. MukerJi, Mycopath. Mycol. appl., 28, 317 (1966).

17) J. N. RAI and J. P. Tewari, Can. J. Botany, 41, 331 (1963).

18) S. A. WAKSMAN and E. Burgie, J. Bacteriol., 48, 527 (1944).

19) P. W. Brain, Bot. Rev., 17, 357 (1951).

20) J. Cummings, Mycologia, 46, 289 (1954).

21) M. Tveit and M. B. Moore, Phytopathology, 44, 686 (1954).

22) T. H. Nicolson, Pl. Dis. Reptr., 44, 774 (1960).

23) K. G. MukerJi, Ph. D. Thesis, Lucknow University, Lucknow, India. (1962).

24) M. Caullery, Parasitism and Symbiosis, Sidgwick and Jackson Ltd., London. (1952).

25) E. F. Butler and T. H. King, Phytopathology, 41, 5 (1951).

26) M. P. Backus and E. A. Stowell, Mycologia, 45, 836 (1953).

27) C. J. DobBs and W. H. Hinson, Nature, 172, 197 (1953).

28) D. J. Morton and W. H. Srroube, Phytopathology, 45, 417 (1955).

29) K. Lilly, Mad. Bhar. J. Univ. Saugar, 9B, 35 (1960).

30) J. G. Smith, Acta. Bot. Neerl., 9, 59 (1960).

31) G. Viennot-B Jurgin, Ann. Inst. Pasteur, 107, 21 (1964).

32) H. A. DADE, Mycologia, 21, 16 (1938).

33) J. E. D: V : , Ann. Rev. Microbiol., 10, 113 (1956).

34) T. T. A ress, Mycologia, 33, 178 (1941).

35) T. Beneder, Phytopathology, 35, 222 (1943).

36) C. C. Livdegren and G. Lindegren, Bot. Gaz., 105, 304 (1944).

37) E. L. H «e , Mycologia, 39, 200 (1947).

38) S. D. Gtik Tr, New Phytol., 50, 149 (1951). 
39) S. D. Garrett, Trans. Brit. mycol. Soc., 41, 157 (1958).

40) R. L. StARKey, Bact. Rev., 22, 154 (1958).

41) H. J. Swart, Acta Bot. Neerl., 7, 741 (1958).

42) T. M. McCalla, Bull. Nebraska Agric. Expt. Sta., 453, 1 (1959).

43) G. W. F. Sewell, Trans. Brit. mycol. Soc., 42, 343 (1959).

44) G. H. Elkan and W. E. C. Moore, J. Elisha Mitch. Sci. Soc., 76, 134 (1960).

$45)$ R. H. Thronton, New Zealand J. Agric. Res., 3, 203 (1960).

46) G. C. Papavizas and C. S. Davey, Phytopathology, 51, 92 (1961).

47) G. C. Papavizas and C. S. Davey, Phytopathology, 51, 693 (1961).

48) E. GRIfFIths, Biol. Rev., 40, 129 (1965). 